Biological and Clinical Sciences Research Journal

ISSN: 2708-2261

www.bcsrj.com

DOI: https://doi.org/10.54112/bcsrj.v2020i1.15

Biol. Clin. Sci. Res. J., Volume, 2020: 15

MEDEYE

Original Research

\title{
AN INVESTIGATION OF THE PROBLEMS FACED BY VEGETABLE GROWERS REGARDING POST- HARVEST PRACTICES IN DISTRICT FAISALABAD
}

\section{KHAN HS, CHAUDHRY KM, ASHRAF I, *USMAN M, EJAZ R, KHADIM MM}

\author{
Institute of Agricultural Extension, Education and Rural Development, University of Agriculture, Faisalabad, \\ Punjab, Pakistan \\ Corresponding author: malikusmanuaf@gmail.com
}

(Received, $5^{\text {th }}$ May 2020, Revised $25^{\text {th }}$ June 2020, Published $9^{\text {th }}$ July 2020)

\begin{abstract}
Vegetables have important role in daily food which have essential nutritionals because they have a significant source of vitamins, sugar and dietary fibre as well as antioxidants. The study was conducted in district Faisalabad. Tehsil Sammundri and Jaranwala were selected purposively, because there are maximum vegetables growers. The population of Jaranwala and Sammundri were 178 and 241 vegetable growers respectively making a total population of 419 according to the list of agricultural extension department. Sample size was 202 by using online software (survey system.com) keeping confidence interval 5\% and confidence level 95\%. Proportionate sampling was used to select the respondents in these two tehsils. By using proportionate sampling respondents of tehsils named Jaranwala and Sammundri were 86 and 116 respectively. Results show that majority of respondents were falling between 41-60 years age interval, cultivating the vegetables. About one third 31.7\% of the respondents were matriculation those farmers having knowledge about education importance and values. Manual washing is method of washing the vegetables by using of clean water this method was ranked 4th, it secured mean value of 3.82. In studied areas mostly farmers were using simple packing including polythene, plastic bags it ranked 6th. About vast majority of $90.1 \%$ respondents have been used the simple packing for vegetables it secured mean value of 3.26. In transportation process of vegetables over whelming majority $99 \%$ of respondents were using less expensive and easily approach able vehicle that was loader Rikshaw, which ranked 1st as compared to other vehicle which secured a mean value of 4.25 . About vast majority $84.2 \%$ respondents were facing the problem of middle man involvement in markets. Middle man has most important role between customer and farmers that was observed, it ranked 17th and it secure mean value of 3.25. There was maximum issue of technology was noticed that they had no awareness regarding the machinery. They had faced the issue of markets and middle man commission. Government should pay attention toward infrastructure, markets governance and reduce the commission of middle man by involving the responsible authorities. Government institutes should deliver the proper guideline related to vegetables post-harvest problems to improve the quality and quantity of products.
\end{abstract}

Keywords: nutrition value, transportation issues, middle man, vegetable processing

\section{Introduction}

Pakistan is developing country with 207 million of population in South Asia. It is the sixth largest populated country, but at GDP level it ranked $43^{\text {rd }}$. Agriculture is the main driving force in the economy of Pakistan as it relates to development, traditional farming practices with outdated technology responsible for stagnant development. Agriculture adds a substantial share of about $18.9 \%$ of Pakistan's GDP, as well as one of the major foreign reserve earners through exports. Agriculture plays an important role in the financial addition of the nation. Employment Trends 2018 and 2019 has shown $37.4 \%$ of the total workers employed in the agricultural sector. Approximately, 64\% of Pakistani population relies directly or indirectly on farming. Agriculture and the related sectors also support the cottage, dairy and food sectors (Pakistan Statistical Bureau, 2018-19). Vegetables are the most important component of our food as they enhance our immune system against chronic diseases. Vegetables must be included in diet for protection against malnutrition and obesity related disorders (FAO, 2010). Roughly 2 to 3 billion people all over the world are suffering from malnutrition, while 925 million people suffer from hunger (FAO, 2009). In developing countries provision of vegetable rich diet remains an uphill task. To overcome the problems of food security and malnutrition is a key concern in Pakistan and other developing countries as $16 \%$ of the population in these countries lack food security (Keatinge et al.,

[Citation: Khan, H.S., Chaudhry, K.M., Ashraf, I., Usman, M., Ejaz, R., Khadaim, M.M. (2020). An investigation of the problems faced by vegetable growers regarding post-harvest practices in district Faisalabad. Biol. Clin. Sci. Res. J., 2020: 15 doi: https://doi.org/10.54112/bcsrj.v2020i1.15]. 
2011). Vegetables are important commercial crops and highly nutritious food commodities. They have healthy source of vitamins, sugar, organic acids, minerals, antioxidants and dietary fibre which are essential for human health (Chun-Ta, 2010). Public media, health agencies and medical research has raised awareness in masses regarding health benefits of fresh and natural foods. There has been raised demand for fresh food in public over use of processed products (Wills et al., 1999).

Improper harvesting methods and post-harvest practices result in loss of agricultural products in Pakistan which became the cause of raising the price of agricultural goods. Efficient post-harvest strategies can save billions of rupees and ensure abundant food supply at all times. Post-harvest losses of agricultural goods are comparatively high in developing countries as compared to the developed world. Approximately, 10-30 \% loss is attributed to post-harvest methods in developing countries including Pakistan (Hanif and Khan, 2004). Fresh harvested vegetables contain high moister content, active metabolism and tender texture. After the harvest main decrease in quality of product occurs due to desiccation, mechanical injuries and microbial spoilage as the products pass through various stages of food value chain (Chun-Ta, 2010). Poor post-harvest practices contribute to poor quality of vegetables. Since poor handling practices after the harvest can cause large losses in products, it has become centre stage of attention for vegetable growers to meet this challenge of post-harvest losses (Wills et al., 1999). In the production process and marketing chain post-harvest losses can occur at any stage. These losses occur during fruit and vegetables storage, transportation and handling process (Kader, 2005). The main causes of food insecurity in developing countries are post-harvest losses. World food production has increased at international level however half of the population in third world countries still suffer from shortage of food availability. Major reason for the difference is food loss occurring through poor post-harvest practices (Babalola et al., 2010). Bachmann and Earles (2000) reported that to reduce the damage like mechanical and discoloration of vegetable and other perishables handled gently. These damages lead to moisture loss and contamination of the products. Such damage could be prevented by usage of bins with internal padding and by harvesting the products at correct maturity. Handling of the products should be done in dry condition if possible to avoid such losses.

Post-harvest losses in vegetables range between 25$40 \%$. The situation leads to socioeconomic losses including decrease in income of farmers and loss to national income. There is a dire need to invest in introducing efficient market structure and distribution channels to reduce post-harvest losses. Agricultural Extension activities have a critical role to play for the benefit of vegetable growers, traders and consumers (Kumari and Pankaj, 2015). Post-harvest loss reduction can substantially contribute to enhance the living standard of rural community. In order to reduce post-harvest losses it is important to increase the availability of vegetable at house hold level. Current status of post-harvest practices is a challenge due to poor handling, sorting, grading, transportation, storage and processing of vegetables after harvesting of vegetables. A number of factors including lack of information and resources contribute to post harvest losses. There is a need for an investigation into the problems faced by vegetable growers regarding development of post-harvest practices. The key purpose of the current study was to investigate the problems faced by vegetable growers regarding postharvest practices. The study also was aim to analyze alternative solutions to avoid post-harvest losses of vegetables in district Faisalabad.

\section{Materials and methods}

Researcher personally interviewed farmers in their homes or farms. Although the interview schedule was constructed in English and Urdu, the questions were administered in Punjabi language for the convenience of interviewees in order to obtain the necessary information with maximum accuracy. During the interview, the investigator attempted his best to keep an informal and pleasant environment in order to acquire the views of the sample participants. The purpose of the study was to investigate the problems faced by vegetables growers regarding post-harvest practices in district Faisalabad. There are six Tehsils in District Faisalabad, name as Faisalabad city, Jaranwala, Sammundri, Chak Jhumra, Tandaliawala, and Faisalabad Sadar. Sammundri and Jaranwala Tehsils are selected purposively, because there are maximum vegetables growers. The population of Jaranwala and Sammundri is 178 and 241 respectively making a total population of 419 according to the list of agricultural extension department. Sample size was 202 by using online software (survey system.com) keeping confidence interval 5\% and confidence level 95\%. Proportionate sampling was used to select the respondents in these two tehsils. By using proportionate sampling respondents of tehsils named Jaranwala and Sammundri were 86 and 116 respectively. A wellstructured interview schedule was used for the

[Citation: Khan, H.S., Chaudhry, K.M., Ashraf, I., Usman, M., Ejaz, R., Khadaim, M.M. (2020). An investigation of the problems faced by vegetable growers regarding post-harvest practices in district Faisalabad. Biol. Clin. Sci. Res. J., 2020: 15 doi: https://doi.org/10.54112/bcsrj.v2020i1.15]. 
collection of data. Research data were analyzed by using computer software SPSS.

\section{Results and discussion}

Age (Figure 1) is considered one of the major among several different demographic attributes which may influence the behavior of the respondents towards different features of agriculture and can also influence the respondents' perceptions (Allahyari et al., 2008). Age is a vital role playing characteristic in such a way that it could have negative or positive impact on the process of adoption concerning the behavior of the farming community. (Hossain, 1972). Contrary views in this regard are also given in literature (Kotile and Martins, 2000). That is why, it was mandatory to discover about the age of respondents. According to results more than half $(52.5 \%)$ of the respondents were between the age of 41-60 years. Attaullah (2014) also represented the same results according to which simple majority

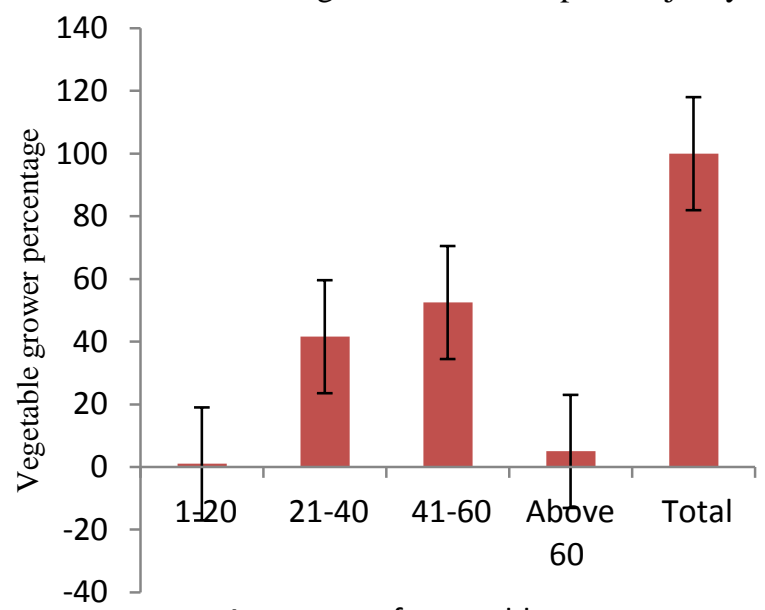

Age range of vegetable growers
(55.8\%) farmers were belonging to middle age category in cotton areas of the Punjab, Pakistan. Education is a vital role playing feature in the process of adoption of innovative agricultural practices (Jariko et al., 2011; Sulo et al., 2012). Education (Figure 1) brings improvement in knowledge level and other desired abilities of mind and formal education plays a vital role in this regard. It is true that a person who is well educated is more likely to approach more positively, logically and analytically towards different things in different matters (Amir, 2003). Educational status was $31.7 \%$ of the respondents were matriculation. About $10.9 \%$ were illiterate farmers those observed in the recommended area were far away from education. Chaudhry et al. (2008) also described that $21.4 \%$ of the respondents were not literate and almost $19 \%$ of the respondents were literate up to level of matriculations.

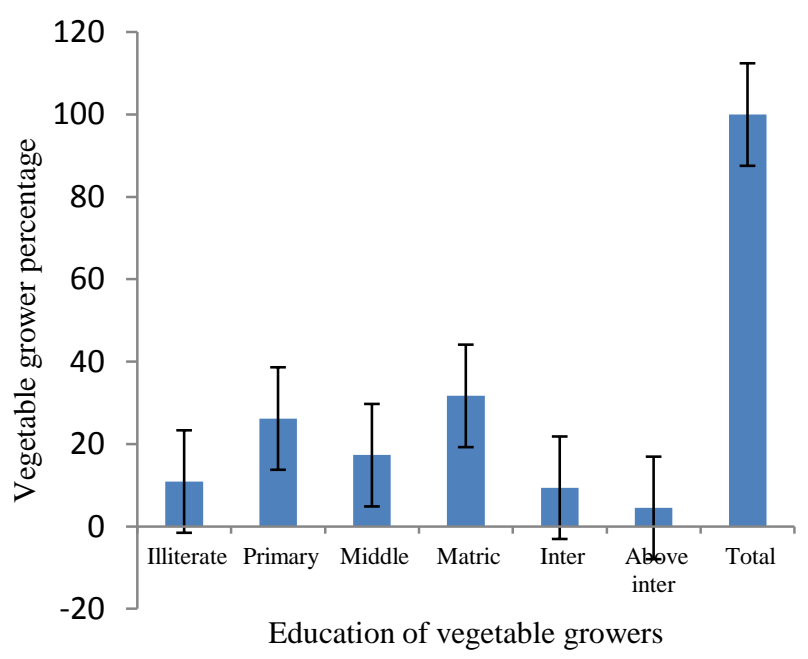

Figure 1. Age range and education percentage of vegetable growers

Post-harvest losses expression in the world is "Degradation in the quality and quantity of the crop products from harvesting to the consumer use". Inappropriate post-harvest handling can cause the losses in quality and quantity in agricultural crops. It is also responsible for the increase of price of agricultural products in Pakistan. Agriculture experts believed that, these losses responsible for the less return back to the farmers, effect to processors and cause loss for traders and country income also effect in foreign exchange (Ali, 1991). That's why, these losses are in billions, this is danger alarm for the world as increasing population fastly and at the same rate resources are not producing for the hunger and speedily increasing population reducing the postharvest losses are the main goal for the agricultural and the food scientist. The post-harvest in cereal crops, fresh vegetables and fruits in the resulting of disorder and infectious disease, which really different in the production area, commodities and seasons. Both quality and quantity are the main cause of the loss in agricultural benefits, these are in the response of stress related to excessive heat or cold, inappropriate mixture of environmental gasses and most important in adequate storage, transportation and most important is the poor nutrient management (Abbas, 2006). Extra losses also occur due to the mechanical damage like cutting, excessive pooling and trimming. Fresh fruits and vegetables are mostly soft to mechanical injury. Poor handling, improper packing and careless transport can increase the losses. All the above factors are not caused by any disease microbes or organisms, so by adopting new

[Citation: Khan, H.S., Chaudhry, K.M., Ashraf, I., Usman, M., Ejaz, R., Khadaim, M.M. (2020). An investigation of the problems faced by vegetable growers regarding post-harvest practices in district Faisalabad. Biol. Clin. Sci. Res. J., 2020: 15 doi: https://doi.org/10.54112/bcsrj.v2020i1.15]. 
technology the losses can be reduced, because these all losses are due to improper management in post harvesting. Sometime these factors can weak the natural defense against the pathogens. The attack on vegetables and fruit from insects, bacteria, fungi and other microorganisms are the major factor in postharvest losses in the fruits and vegetables. Microorganisms attack fresh produce and spread rapidly in the fruits and vegetables due to the lack of natural defense in plants. Excess nutrients in plant and more moisture support the growth of microorganisms (Fadare et al., 2014).

Pakistan is the developing country, where 35-40 percent post-harvest losses are in fruits and vegetables. In these losses 15-20 percent are at the time of management harvested crop, 5-8 percent at harvesting and 10-12 percent loss in vegetable and fruits when it transport. Agro-climatic conditions in Pakistan vary from tropical region to temperate regions, where 40 different types of vegetables, 20 types of fruits are produced in Pakistan. In the developing countries the losses are more due to unawareness about the new technology and peoples adopt the old processes, but in the developed countries these losses are less as compared to developing countries. In developing countries the losses are 10-30 percent, this is a big loss for the farmers and country. The income of the farmers is very low or less profit due to the quality and quantity. In the developed countries the losses are just 1 percent (Agri Hunt, 2018). Pakistan falls in the list of developing countries. In Pakistan the total fruits and vegetables are produced nearly 13.674 million tons, it is expected that $30-40$ percent goes to waste. More than 50 percent in mulberry, apricots, cherry, while in almond and walnuts is 6 percent. In horticultural crops the 40 percent low price as compared to the world average price due to the low standard of post harvesting management. In India these losses are similar as in Pakistan because both are developing countries and lack of new technologies. Post-harvest losses in wheat are 10 percent and in the rice losses are 15 percent in Pakistan (Agri Hunt, 2018).

Table 1.To assess the knowledge level of vegetable growers on post-harvest practices

\begin{tabular}{|c|c|c|c|c|}
\hline \multirow[t]{2}{*}{ Post-harvest practices } & \multicolumn{2}{|c|}{ Frequency } & \multicolumn{2}{|c|}{ Percentage (\%) } \\
\hline & Yes & No & Yes & No \\
\hline Hydro cooling & 155 & 47 & 76.7 & 23.3 \\
\hline Cool water spray & 147 & 55 & 72.8 & 27.2 \\
\hline Disinfecting & 136 & 66 & 67.3 & 32.7 \\
\hline Manual washing & 174 & 28 & 86.1 & 13.9 \\
\hline Machines & 10 & 192 & 5.00 & 95.0 \\
\hline Tray & 154 & 48 & 76.2 & 23.8 \\
\hline Bags & 126 & 76 & 62.4 & 37.6 \\
\hline Use of box & 110 & 92 & 54.5 & 45.5 \\
\hline Simple packing & 182 & 20 & 90.1 & 9.90 \\
\hline Use of baskets & 185 & 17 & 91.6 & 8.40 \\
\hline Plastic bags & 194 & 8 & 96.0 & 4.00 \\
\hline Crate box & 194 & 8 & 96.0 & 4.00 \\
\hline Old cartloads & 169 & 33 & 83.7 & 16.3 \\
\hline tractor trolley & 181 & 21 & 89.6 & 10.4 \\
\hline Mini truck & 173 & 29 & 85.6 & 14.4 \\
\hline Rikshaw & 200 & 2 & 99.0 & 1.00 \\
\hline
\end{tabular}

Table2. Ranking of the respondents regarding post-harvest practices on their weighted Score, Mean and Std. Deviation

\begin{tabular}{lcccc}
\hline Post-harvest practices & Weighted score & Mean & Std. Deviation & Rank \\
\hline Rikshaw & 791 & 4.25 & 0.90 & 1 \\
Plastic bags & 744 & 3.83 & 0.96 & 2 \\
Use of baskets & 646 & 3.53 & 0.81 & 3 \\
Manual washing & 642 & 3.82 & 1.02 & 4 \\
Crate box & 628 & 3.25 & 1.04 & 5 \\
Simple packing & 594 & 3.26 & 0.69 & 6 \\
Old cart loads & 541 & 3.05 & 1.05 & 7 \\
Mini truck & 528 & 2.90 & 1.27 & 8 \\
Tray & 490 & 3.24 & 0.95 & 9 \\
\hline
\end{tabular}

[Citation: Khan, H.S., Chaudhry, K.M., Ashraf, I., Usman, M., Ejaz, R., Khadaim, M.M. (2020). An investigation of the problems faced by vegetable growers regarding post-harvest practices in district Faisalabad. Biol. Clin. Sci. Res. J., 2020: 15 doi: https://doi.org/10.54112/bcsrj.v2020i1.15]. 


\begin{tabular}{lcccc}
\hline Tractor trolley & 490 & 2.73 & 1.28 & 10 \\
Cool water spray & 447 & 3.08 & 1.18 & 11 \\
Bags & 439 & 3.42 & 1.16 & 12 \\
Disinfecting & 432 & 3.06 & 0.95 & 13 \\
Use of box & 367 & 3.11 & 1.31 & 13 \\
Hydro cooling & 406 & 2.74 & 0.87 & 14 \\
Machines & 74 & 3.52 & 0.87 & 15 \\
\hline
\end{tabular}

Manual washing is process of washing of the products, was noticed as maximum growers was know how to wash the vegetables their weighted score was 642 and their mean value observed as 3.82 and its ranked $4^{\text {th }}$. Use of machines for the washing of vegetables their use was very low farmers have no knowledge about machines their weighted score was 74 and according to this results mean founded 3.52 and its rank $15^{\text {th }}$ at the end value of std. deviation founded as 0.87 . In packing process there different techniques in which simple packing was weighted score 594 , its mean value stated as 3.26 , on the base of these values its ranked $6^{\text {th }}$ and Std .deviation value observed as 0.69 . Rikshaw was most common vehicle that was used by maximum growers to carrying the vegetables to market it was easy to access and cheap as compare to other source of transportation that's why it's used commonly by both small scale and large scale farmers its weighted score value was 791, its mean value was 4.25 , its rank was $1^{\text {st }}$ and its standard deviation value was 0.90 . In this study less than half $44.1 \%$ of farmers were facing mechanical loss and they had knowledge about this loss and on the other side more than $55.9 \%$ of farmers were having no knowledge regarding mechanical losses. Similarly over whelming majority $91.1 \%$ of respondents were having careless handling damage of the products and $8.9 \%$ of respondents were having no knowledge regarding careless handling. During the transportation of vegetables maximum damages in which carelessness of labor has main impact on production loss 194 respondents responds toward caress labor working during transportation over whelming majority $96 \%$ of respondents were having this loss. Bad roads have impact on products loss while transportation in post-harvest practices. In study area there was road condition was normal and in maximum area road to market were not in good condition but in some areas roads were in very fine condition. Large majority $82.2 \%$ of respondents were having this loss. Environmental factors also impact on vegetables high temperature loss and damages of over whelming majority $97.5 \%$ of respondents were facing this loss and $2.5 \%$ of respondents were having no issue. According to the results awareness to market is important factor that's why maximum grower has no awareness, about large majority $88.6 \%$ of respondents were facing this loss and the other $11.4 \%$ of respondents were having no loss regarding awareness of markets. Middle man has character to improve the production of vegetables by impressing the growers to good behavior and good price of product so large majority $84.2 \%$ of respondents were predicting this issue. In this study according to the results there were many factors that were under the study. In this objective mainly focus on the techniques/technology discussed so according to the study purpose and the results assessing the maturity of the vegetables was main factor maximum respondents 202 had the knowledge regarding the maturity level of vegetables their percentage was noticed $100 \%$ farmers had knowledge about the maturity. There was no trend of control packing 20 respondents respond in positive way and 182 respondents did not the refrigerating the vegetables they were $90.1 \%$. Similarly only $19.8 \%$ of farmers were responding that modified freezing was not common in farmers .Refrigerator loading was common factor 147 and $72.8 \%$ respondents had knowledge about the refrigerator loading and the 55 and $27.2 \%$ respondents had no knowledge. Cooling of truck was common practices large majority $93.6 \%$ of respondents had knowledge and $6.4 \%$ of respondent had no knowledge. Insulator plastic sheets were used to prevent the vegetables from temperature heat manually prepared sheet and $77.7 \%$ of respondents had knowledge about the insulator sheet whereas, $22.3 \%$ respondents had no knowledge about this factor.

\section{Summary}

$>\quad$ It can be concluded that vegetables postharvest practices in the study area was too simple. Also, there was a positive relationship between the age of the farmers and post -harvest practices. Constraints were also major barriers to effective post-harvest practices in the study area.

Study was concluded that in research area Tehsil sammundri and Tehsil Jaranwala in District Faisalabad there was maximum vegetables growers have knowledge regarding the post-harvest practices. They had knowledge regarding the harvesting of the products, product washing, packing of the vegetables,

[Citation: Khan, H.S., Chaudhry, K.M., Ashraf, I., Usman, M., Ejaz, R., Khadaim, M.M. (2020). An investigation of the problems faced by vegetable growers regarding post-harvest practices in district Faisalabad. Biol. Clin. Sci. Res. J., 2020: 15 doi: https://doi.org/10.54112/bcsrj.v2020i1.15]. 
sorting and grading of the vegetables which was most important that has impact on the production. There were maximum growers had knowledge regarding the transportation of the vegetables to the markets, maximum use of the Rikshaw for transferring the vegetables to the market.

$>\quad$ In study area maximum growers were growing Ridge Gourd, Butternut Squash, Bitter Gourd, Chilly, Spinach, Okra, Tomato and Carrot. There was maximum growers had faced problems regarding the post-harvest practices, Mechanical loss, Careless handling, Packing damages these problem were observed which concluded that farmers faced post-harvest losses.

$>\quad$ In research area there was problem of transportation of vegetables to markets there was not proper link roads to main roads and main roads were also not in good condition that's why farmers faced a lot of hurdles regarding the transportation of vegetables, therefore vegetables growers facing these issue as post-harvest losses, in shape of products injuries.

$>\quad$ There was problem of labor they faced carelessness of the labor during the transportation while loading the products and unloading of the products they damaged the products which become cause of losses.

$>\quad$ In study area observed that environmental factor has impact on the quality of the vegetables environmental factors include the both high temperature and high humidity in some cases noticed that high temperature damaged the products which became cause of post-harvest losses and similarly high humidity become cause of diseases which spoiled the products.

$>\quad$ Market issue was also noticed there was no proper channel of marketing commission of middle man and un awareness from product price ,market access due to lack of resources there was an issue that has been faced by the vegetable grower in the form of post-harvest losses.

\section{Conflict of interest}

The authors declared absence of any type of conflict of interest for manuscript publication.

\section{References}

Abbas, M.A. (2006). General Agriculture. Emporium Publishers, Lahore, Pakistan.

Ali, A. (1991). A study into the adoption of recommended rice growing practices in tehsil Shakargarh of district Sialkot. M.Sc. (Hons.) Thesis, Dept. of Agri. Ext., Uni. of Agri., Faisalabad, Pakistan.

Allahyari, M. S., Chizari, M., \& Homaee, M. (2008). Perceptions of Iranian agricultural extension professionals toward sustainable agriculture concepts. Journal of Agriculture and Social Sciences, 4(3), 101-106.

Amir, J. (2003). An investigation into the adoption of broiler production/ management practices by poultry farmers in tehsil Samundri. M.Sc. (Hons.) Thesis, Dept. of Agri. Ext., Uni. of Agri., Faisalabad, Pakistan

Attaullah. (2014). Analysis of factors affecting the cotton production in tehsil Muzaffargarh. M.Sc. (Hons.) Thesis, Inst. of Agri. Ext. \& Rural Dev., Uni. of Agri., Faisalabad, Pakistan.

Babalola, D. A., Makinde, Y. O., Omonona, B. T., \& Oyekanmi, M. O. (2010). Determinants of post-harvest losses in tomato production: a case study of Imeko-Afon local government area of Ogun state. Acta Satech, 3(2), 14-18.

Bachmann, J., \& Earles, R. (2000). Postharvest handling of fruits and vegetables. Appropriate technology transfer for rural areas. Fayetteville, Arizona: ATTRA.

Chaudhry, K. M., Muhammad, S., Saghir, A., \& Ashraf, I. (2008). Rural women's access to various sources of information in tehsil Faisalabad. Journal of Animal and Plant Science, 18(2-3).

Chun-Ta, W. (2010). An overview of postharvest biology and technology of fruits and vegetables. In Technology on Reducing Postharvest Losses and Maintaining Quality of Fruits and Vegetables: Proceedings of 2010 AARDO Workshop.

Fadare, O. A., Akerele, D., \& Toritseju, B. (2014). Factors influencing adoption decisions of maize farmers in Nigeria. International Journal of Food and Agricultural Economics (IJFAEC), 2(1128-2016-92049), 45-54.

FAO. (2009). FAOSTAT on-line. Rome: United Nations Food and Agriculture Organization. http://faostat.fao.org/default.aspx.

FAO. (2010). The state of food insecurity in the world: Addressing food insecurity in the protracted crises. Food and Agriculture Organization of the United Nations Rome.

Govt. of Pakistan. (2017-18). Education: Economic Survey of Pakistan. Economic advisory wing, Ministry of Finance, Pakistan.

Hanif, M., Khan, S., \& Nauman, F. (2004). Agricultural perspective and policy. Ministry of Food, Agriculture and Livestock (MINFAL), Islamabad.

Hossain, M. A. (1972). Adoption of improved farm practices by the transplanted of Mymensingh district. Research in agricultural extension (a compilation of Master'Thesis, 1960-90), BAU, Mymensingh.

[Citation: Khan, H.S., Chaudhry, K.M., Ashraf, I., Usman, M., Ejaz, R., Khadaim, M.M. (2020). An investigation of the problems faced by vegetable growers regarding post-harvest practices in district Faisalabad. Biol. Clin. Sci. Res. J., 2020: 15 doi: https://doi.org/10.54112/bcsrj.v2020i1.15]. 
https://agrihunt.com/articles/pak-agri-outlook/postharvest-losses-in-fruits-and-vegetables-inpakistan/

Jariko, G. A., Junejo, M. A., Rahpoto, M. S., \& Shah, M. Z. (2011). Socioeconomic factors affecting adoption of sunflower varieties in Sindh. Pakistan Journal of Commerce and Social Sciences (PJCSS), 5(1), 192-201.

Kader, A. A. (2005). Increasing Food Availability by Reducing Postharvest Losses of Fresh Produce UC Davis.

Kader, A. A., \& Rolle, R. S. (2004). The role of postharvest management in assuring the quality and safety of horticultural produce (Vol. 152). Food \& Agriculture Org.

Keatinge, J. D. H., Yang, R. Y., Hughes, J. D. A., Easdown, W. J., \& Holmer, R. (2011). The importance of vegetables in ensuring both food and nutritional security in attainment of the Millennium Development Goals. Food Security, 3(4), 491-501.

Kereth, G. A., Lyimo, M., Mbwana, H. A., Mongi, R. J., \& Ruhembe, C. C. (2013). Assessment of post-harvest handling practices: knowledge and losses of fruits in Bagamoyo district of Tanzania. Journal of Food Quality Management, 11.

Kinyuru, J. N., Kahenya, K. P., Muchui, M., \& Mungai, H. (2011). Influence of post-harvest handling on the quality of snap bean (Phaseolus vulgaris L.). Journal of Agriculture Food and Technology, 1(5), 43-46.

Kitinoja, L., Saran, S., Roy, S. K., \& Kader, A. A. (2011). Postharvest technology for developing countries: challenges and opportunities in research, outreach and advocacy. Journal of the Science of Food and Agriculture, 91(4), 597-603.

Kotile, D. G., \& Martin, R. A. (2000). Sustainable agricultural practices for weed management: Implications to agricultural extension education. Journal of Sustainable Agriculture, 16(2), 31-51.

Kumari, A., \& Pankaj, P. P. (2015). Post-Harvest Losses of Agricultural Products: Management and Future Challenges in India.

Mbuk, E. M., Bassey, N. E., Udoh, E. S., \& Udoh, E. J. (2011). Factors influencing post-harvest loss of tomato in urban market in Uyo, Nigeria. Nigerian Journal of Agriculture, Food and Environment, 7(2), 40-46.

Wills, R., McGlasson, B., Graham, D., \& Joyce, D. (19999). Postharvest: An introduction to the physiology and handling of fruit, vegetable and ornamentals. Journal of Vegetable Crop Production, 4(2):83-4.
Muda, M. N. (2006). Post-harvest Handling. Postharvest Management of Fruit and Vegetables in the Asia Pacific Region (pp. 187-190). New Delhi: Asian Productivity Organization.

Naidoo, K. D. (2009). The practice, constraints and perceptions of improving soil quality through manure application: a case study of three smallholder farmer groups (Doctoral dissertation).

Pakistan Bureau of Statistics, (2018-19). Education: Economic Survey of Pakistan. Economic advisory wing, Ministry of Finance, Pakistan.

Rico, D., Martin-Diana, A. B., Barat, J. M., \& BarryRyan, C. (2007). Extending and measuring the quality of fresh-cut fruit and vegetables: a review. Trends in Food Science \& Technology, 18(7), 373-386.

Sulo, T., Koech, P., Chumo, C., \& Chepng'eno, W. (2012). Socioeconomic factors affecting the adoption of improved agricultural technologies among women in Marakwet County Kenya. Journal of Emerging Trends in Economics and Management Sciences, 3(4), 312-317.

Wegner, and Zwart L.G. (2011). Who will feed the world? The production challenge. United Kingdom: Oxfam.

\section{(2) $(1) \Theta$}

Open Access This article is licensed under a Creative Commons Attribution 4.0 International License, which permits use, sharing, adaptation, distribution and reproduction in any medium or format, as long as you give appropriate credit to the original author(s) and the source, provide a link to the Creative Commons licence, and indicate if changes were made. The images or other third party material in this article are included in the article's Creative Commons licence, unless indicated otherwise in a credit line to the material. If material is not included in the article's Creative Commons licence and your intended use is not permitted by statutory regulation or exceeds the permitted use, you will need to obtain permission directly from the copyright holder. To view a copy of this licence, visit http://creativecommons.org/licen ses/by/4.0/.

(C) The Author(s) 2021

[Citation: Khan, H.S., Chaudhry, K.M., Ashraf, I., Usman, M., Ejaz, R., Khadaim, M.M. (2020). An investigation of the problems faced by vegetable growers regarding post-harvest practices in district Faisalabad. Biol. Clin. Sci. Res. J., 2020: 15 doi: https://doi.org/10.54112/bcsrj.v2020i1.15]. 
[Citation: Khan, H.S., Chaudhry, K.M., Ashraf, I., Usman, M., Ejaz, R., Khadaim, M.M. (2020). An investigation of the problems faced by vegetable growers regarding post-harvest practices in district Faisalabad. Biol. Clin. Sci. Res. J., 2020: 15 doi: https://doi.org/10.54112/bcsrj.v2020i1.15]. 